\title{
Is There Such a Thing as a Free Lunch?
}

BY

Gail K. McCracken and Thomas J. Callahan

Gail K. McCracken is an Assistant Professor in the School of Management at the University of Michigan-Dearborn. She earned her J.D. degree from Wayne State University. Her research interests include the impact of legal and ethical forces on business relationships.

Thomas J. Callahan is an Assistant Professor in the School of Management at the University of Michigan-Dearborn. He earned his Ph.D. degree from Michigan State University. His research interests include buyer-supplier relationships and decision-making processes.

\section{IN BRIEF}

Analysis of data from 179 respondents indicated that the concept of the business lunch is alive and well among both purchasing and sales professionals. Neither the purchasing nor sales professionals believed that there was a possibility for a high level of ethical conflict in a majority of the business lunch scenarios they were asked to consider. However, there were significant differences between the sales and purchasing people when asked about the legitimate purposes of the lunch. Moreover, female purchasers were more likely to disagree with the social purposes of the business lunch than were their male counterparts. Implications of these findings and suggestions for future research are discussed.

\section{BACKGROUND FOR THE STUDY}

We practice of a salesperson treating a purchaser to a "business lunch" is and always has been a common business practice. Research has indicated that both purchasing and marketing people believe that the practice is a generally acceptable form of business conduct. ${ }^{1}$ Specifically, recent studies ${ }^{2}$ have indicated that among purchasing personnel, lunches were the most frequently offered and accepted supplier favor.

Business practices involving close semi-social relationships, such as the business lunch, appear to be important to the conduct of effective buyerseller relationships. ${ }^{3}$ Underlying the concepts of close buyer-supplier relationships and strategic alliances between firms is the implication that relationships between firms will extend beyond arm's-length business exchanges to ties based on personal trust and respect. ${ }^{4}$ However, an underlying principle of purchasing practice, advocated by the National Association of Purchasing Management (NAPM), is the avoidance of situations that might influence, or even appear to influence, purchasing decisions. This is particularly emphasized where gratuities are involved. ${ }^{5}$

In practice, purchasing personnel believe that allowing personalities to influence the buying/selling transaction is one of eight problem situations that can be particularly troublesome. ${ }^{6}$ The offer or acceptance of free gifts, meals, and trips is also placed in this problem category by purchasing 
participants in the same study. Given the complexity of these concepts, the point at which relationship building crosses the line and becomes a conflict of interest has become more difficult to discern. ${ }^{7}$

The increasing conflict in perception of the business lunch as an ethical practice is indicated in a 1990 study, in which 83 percent of the buyers were offered lunches by suppliers, but only 68 percent of these buyers found this practice to be acceptable. ${ }^{8}$ Sales representatives, on the other hand, have expressed less ethical concern about the practice of giving or accepting gifts and lunches than have purchasing professionals. ${ }^{9}$ Moreover, many organizations restrict or prohibit their purchasing personnel from accepting a supplier's offer of lunch, but allow and even encourage their own sales personnel to take customers to lunch, leading to an almost schizophrenic attitude toward this practice within the same organization. ${ }^{10}$

Research indicates that in the future there will be increasing pressure for firms to demonstrate a sense of social responsibility and an awareness of ethical problems. Clearly, this suggests a need to review sales techniques including gift giving, business lunches, and entertainment. ${ }^{11}$

Given the differences in perceptions and inconsistent policies, coupled with the widespread participation in this practice, the authors undertook the present study to examine circumstances affecting the ethics-based attitudes toward and purposes served by the business lunch. The study attempts to determine the scenarios in which purchasing and sales personnel consider a free lunch to be ethically acceptable-and, conversely, whether there are conditions or circumstances that would create an ethical conflict. Finally, the study examines the business purposes accomplished by the business lunch, as perceived by both purchasers and suppliers.

\section{HOW THE STUDY WAS CONDUCTED}

Five hundred purchasing professionals and 500 sales representatives were selected randomly from a nationwide professional mailing list (for industrial purchasing and sales people) obtained from a major firm in this business. These potential participants were each sent a copy of the survey instrument, along with a cover letter explaining the research project, defining the terms used in the study, and requesting their participation in the study.

A preaddressed postcard was included so respondents could request an executive summary of the results of the survey. After two weeks, a follow-up letter was sent to all potential participants thanking those who had returned the survey and asking those who had not returned it to respond. A second copy of the survey was included in this mailing.

\section{The Survey Instrument}

The questionnaire included demographic questions about each respondent's gender, age, position title, responsibility level, and so forth. The demographics for the participants in the study are summarized in Table I.

The survey contained 13 items designed to assess the respondents' beliefs about the appropriateness of accepting a free business lunch under a variety of different operating situations. A fivepoint scale was used for responses, ranging from a very high possibility of ethical conflict to a very low possibility of ethical conflict. The second portion of the survey included ten items designed to assess the respondents' beliefs about the purposes for the business lunch. The responses for these items also were assessed using a five-point scale, with anchors ranging from strongly agree to strongly disagree. The 23 research questions included in the survey were based on a search of previous research on ethics in the marketing and purchasing fields, along with information gained through informal interviews with professional purchasing and sales people.

The survey instrument was pretested to identify potential confusion about concepts presented or about wording problems in specific items. Feedback resulted in a refinement of the final version of the instrument.

TABLE

SAMPLE DEMOGRAPHICS

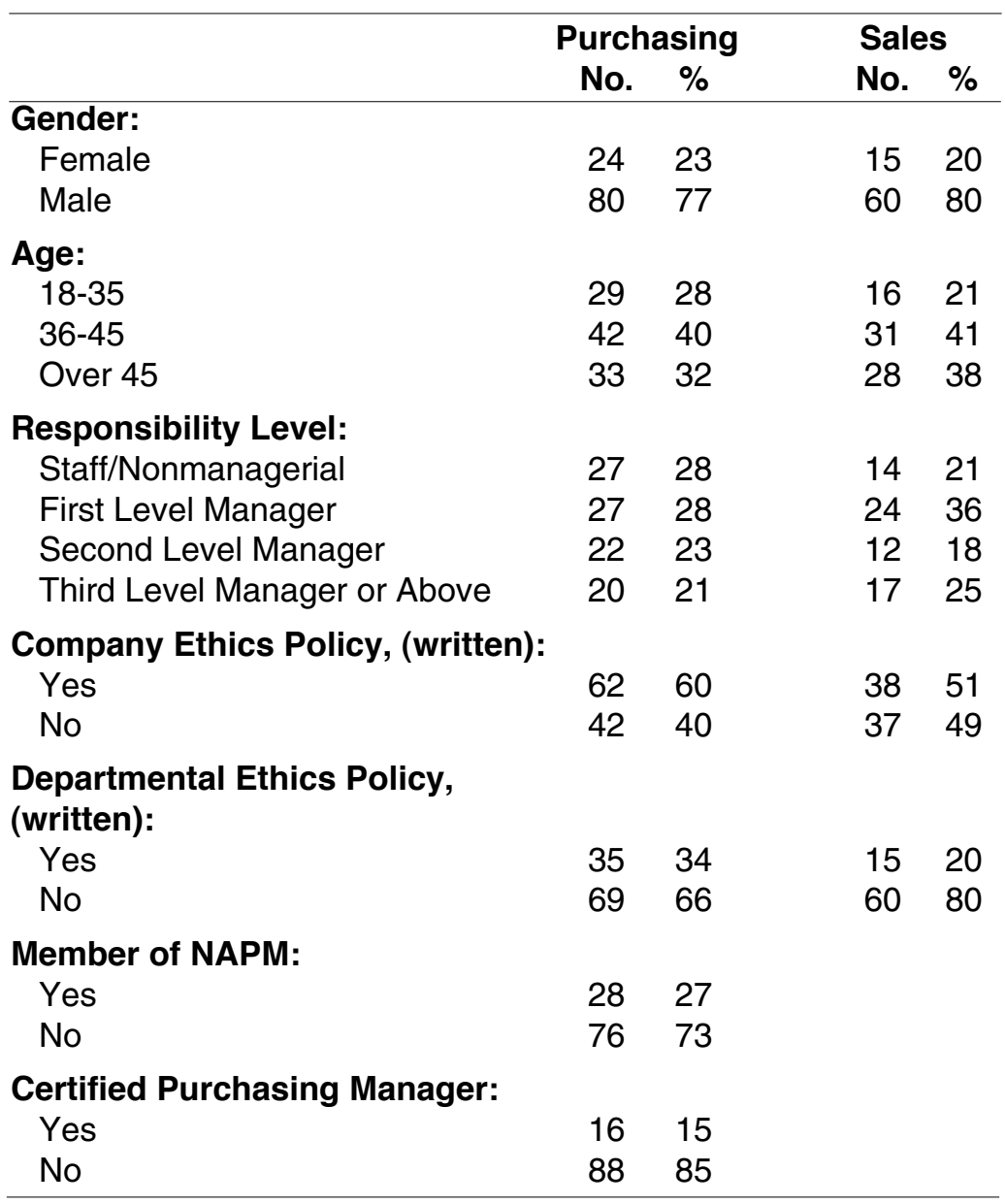




\section{Characteristics of the Participants}

One hundred seventy-nine useable questionnaires were returned by the purchasing and sales participants. This represented an overall response rate of 18 percent-21 percent for the purchasers and 15 percent for the sales group. Although the demographic data for the participants are summarized in Table I, several items are of particular interest:

- $23 \%$ of the responding purchasers were women

- $20 \%$ of the responding sales representatives were women

- $21 \%$ of the purchasers were upper-level managers

- $25 \%$ of the sales respondents were upper-level managers

- $27 \%$ of the purchasers were members of NAPM

- $15 \%$ of the purchasers were Certified Purchasing Managers

Additionally, 55 percent of the companies for which the professional participants worked had a written ethics policy or code of conduct, and onethird of the sample stated that their companies' ethics code specifically covered business lunches.

\section{How the Data Were Analyzed}

For each of the survey questions, the participants' five-point scale responses were analyzed as follows. The "very high" and "high" responses for possibilities of ethical conflict associated with the business lunch were combined into a single response category. Likewise, the "very low" and "low" possibilities of ethical conflict were combined into a second response category. The same procedure was followed to create "agreement" and "disagreement" percentage responses to the questions dealing with purposes for the business lunch. The percentages of the sample falling into these categories, along with the means and the standard deviations of the full-scale items, are presented for purchasing professionals in Table II and sales professionals in Table III (see p. 48). ${ }^{*}$

\section{WHAT THE RESEARCHERS LEARNED FROM THE STUDY}

With the exception of three business lunch scenarios, fewer than 20 percent of the purchasing professionals (usually in the range of $10-15$ percent) saw any significant chance of an ethical conflict occurring. The three circumstances surrounding a business lunch that were viewed as those that might produce some degree of ethical conflict were:

1. Going to lunch with people the purchaser likes

2. Accepting lunch when all potential suppliers have similar cost structures and are offering similar prices

*The Mann-Whitney U-Wilcoxon Rank Sum W Tests were used in determining if any significant differences existed between the responses of the purchasing group and the sales group.
3. Avoiding lunch with individuals the purchaser does not like

On the other hand, with the exception of three other scenarios, less than 10 percent of the sales representatives saw any significant possibility of an ethical conflict resulting from the various business lunch scenarios; and for these three, the percentages were quite low-13, 14, and 12 percent respectively. These three questionable scenarios were:

1. When the product from one supplier is as good as the product from any other supplier

2. When lunch is purely for social purposes

3. When the lunch is avoided with purchasers the sales representatives does not like

The discussion turns now to consideration of the various purposes that can be served by the business lunch. Purchasing and sales professionals agreed most strongly about the legitimacy of the same two purposes, namely:

- A serious business lunch is an important vehicle to use in developing useful business relationships

- A business lunch presents an opportunity for both parties to develop a deeper personal understanding of those with whom they deal

The third most important purpose for sales personnel was their belief that negotiations usually are more productive in a relaxed atmosphere. While approximately 40 percent of the purchasers agreed with this view, all but 12 percent of them clearly stated that a business lunch was not an influential factor that affected purchasing decisions.

Purchasing and sales professionals alike strongly disagreed about the legitimacy of three of the proposed luncheon purposes:

1.Such a lunch is part of one's total compensation package

2. A business lunch is a subtle payoff to the purchaser for doing business

3. A business lunch plays an important role in making sales

\section{Differences Between the Purchasing and Sales Views}

Significant differences between the views of the purchasing and sales groups, along with their means and standard deviations, are detailed in Table IV (see p. 49).

From a statistical point of view, the two groups differed significantly in their perceptions of the possibility of ethical conflict in the case of only one scenario-lunch after the contract has already been awarded. Although both groups thought the possibility of an ethical conflict was relatively low, the sales representatives thought the possibility was significantly lower than did the purchasers. 
TABLE II

PURCHASING PROFESSIONALS' PERCEPTIONS ABOUT BUSINESS LUNCHES

\section{Circumstances Surrounding Lunch (Scenarios)}

1. The supplier offers clearly superior quality and cost advantages.

2. My input into the purchasing decisions is minor; I may state a preference but someone else will make the decision.

3. I don't go to lunch with individuals if I don't enjoy spending time with them.

4. Lunch with the supplier is a rare or very infrequent event.

5. The product from one supplier is as good as the product from any other.

6. The supplier has already been awarded the contract.

7. The supplier has been awarded a long-term contract and is in a limited or sole supplier relationship with my company.

8. Lunch is purely for social purposes.

9. I reciprocate by buying lunch for the supplier.

10. I only go to lunch with suppliers when I enjoy being with them.

11. All bidding suppliers are offering similar cost structures.

12. Lunch with one possible supplier is no more frequent than lunch with any other.

13. All bidding suppliers are offering similar quality structures.

\section{Purposes of Lunch}

1. Business negotiations with a supplier are more productive in a relaxed atmosphere.

2. The "free lunch" plays an important role in making sales.

3. Trust is easier to establish in a relaxed atmosphere.

4. A "free lunch" is an expression of gratitude for doing business.

5. Business lunches are considered part of my total "compensation package."

6. The concept of the "free lunch" is an integral part of global business practices.

7. The business lunch is an important means of developing business relationships.

8. A business lunch allows me to gain personal understanding of those with whom I deal.

9. The "free lunch" is a subtle payoff for doing business.

10. No professional can be swayed to make a decision because of a "free lunch."

\begin{tabular}{|c|c|c|c|c|}
\hline$n$ & High \% & Low \% & Mean & Std. Dev. \\
\hline 103 & 11 & 76 & 4.22 & 1.19 \\
\hline 101 & 11 & 65 & 3.99 & 1.18 \\
\hline 102 & 22 & 57 & 3.69 & 1.42 \\
\hline 103 & 14 & 73 & 4.04 & 1.26 \\
\hline 103 & 16 & 60 & 3.84 & 1.28 \\
\hline 101 & 14 & 73 & 4.07 & 1.27 \\
\hline 10 & 16 & 72 & 4.10 & 1.33 \\
\hline 102 & 19 & 63 & 3.73 & 1.42 \\
\hline 101 & 14 & 75 & 4.16 & 1.25 \\
\hline 102 & 25 & 57 & 3.54 & 1.47 \\
\hline 102 & 21 & 56 & 3.71 & 1.29 \\
\hline 102 & 11 & 73 & 4.05 & 1.14 \\
\hline 102 & 17 & 62 & 3.85 & 1.26 \\
\hline \multicolumn{5}{|c|}{ Disagree Agree } \\
\hline 97 & 33 & 39 & 3.09 & 1.27 \\
\hline 97 & 69 & 12 & 1.82 & 1.14 \\
\hline 97 & 30 & 37 & 3.09 & 1.26 \\
\hline 97 & 39 & 33 & 2.77 & 1.28 \\
\hline 97 & 78 & 9 & 1.57 & 1.07 \\
\hline 96 & 40 & 29 & 2.77 & 1.27 \\
\hline 97 & 28 & 39 & 3.12 & 1.21 \\
\hline 97 & 26 & 50 & 3.35 & 1.22 \\
\hline 97 & 65 & 14 & 1.95 & 1.26 \\
\hline 97 & 25 & 51 & 3.60 & 1.50 \\
\hline
\end{tabular}

On the other hand, again from a statistical point of view, the purchasing and sales professionals differed significantly with respect to the strength of their views about seven of the ten proposed purposes for the business lunch. For each of these scenarios, the sales people believed more strongly in the legitimacy of the purpose than did their counterparts on the purchasing side of the house. These scenarios, along with their statistical measures, are detailed in Table IV.

Prior to the study, the authors hypothesized that among the purchasing professionals, there would be differences in view based on demographics such as age, gender, and job responsibility. Surprisingly, the 
TABLE III

SALES PROFESSIONALS' PERCEPTIONS ABOUT BUSINESS LUNCHES

\begin{tabular}{|c|c|c|c|c|c|}
\hline Circumstances Surrounding Lunch (Scenarios) & $\mathbf{n}$ & High \% & Low \% & Mean & Std. Dev. \\
\hline $\begin{array}{l}\text { 1. My product clearly has superior quality and } \\
\text { cost advantages. }\end{array}$ & 67 & 7 & 81 & 4.57 & 0.84 \\
\hline $\begin{array}{l}\text { 2. The buyers input into the purchasing decisions is } \\
\text { minor; he or she may state a preference but } \\
\text { someone else will make the decision. }\end{array}$ & 66 & 7 & 68 & 4.20 & 0.99 \\
\hline $\begin{array}{l}\text { 3. I don't go to lunch with individuals if I don't } \\
\text { enjoy spending time with them. }\end{array}$ & 67 & 9 & 62 & 3.97 & 1.15 \\
\hline $\begin{array}{l}\text { 4. Lunch with the customer is a rare or very } \\
\text { infrequent event. }\end{array}$ & 66 & 7 & 62 & 4.18 & 1.05 \\
\hline $\begin{array}{l}\text { 5. The product from one supplier is as good as } \\
\text { the product from any other. }\end{array}$ & 66 & 13 & 47 & 3.77 & 1.20 \\
\hline $\begin{array}{l}\text { 6. My company has already been awarded the } \\
\text { contract. }\end{array}$ & 65 & 3 & 75 & 4.60 & 0.82 \\
\hline $\begin{array}{l}\text { 7. My company has been awarded a long-term } \\
\text { contract and is in a limited or sole supplier } \\
\text { relationship with the purchasing company. }\end{array}$ & 65 & 9 & 69 & 4.32 & 1.15 \\
\hline 8. Lunch is purely for social purposes. & 67 & 14 & 60 & 3.91 & 1.36 \\
\hline $\begin{array}{l}\text { 9. The purchaser reciprocates by buying } \\
\text { lunch for me. }\end{array}$ & 66 & 9 & 70 & 4.33 & 1.18 \\
\hline $\begin{array}{l}\text { 10. I only go to lunch with purchasers when I } \\
\text { enjoy being with them. }\end{array}$ & 66 & 12 & 60 & 3.98 & 1.23 \\
\hline $\begin{array}{l}\text { 11. All bidding suppliers are offering similar } \\
\text { cost structures. }\end{array}$ & 66 & 9 & 57 & 4.01 & 1.14 \\
\hline $\begin{array}{l}\text { 12. Lunch with one possible customer is no } \\
\text { more frequent than lunch with any other. }\end{array}$ & 67 & 4 & 66 & 4.22 & 1.01 \\
\hline $\begin{array}{l}\text { 13. All bidding suppliers are offering similar } \\
\text { quality structures. }\end{array}$ & 65 & 8 & 58 & 4.09 & 1.09 \\
\hline Purposes of Lunch & \multicolumn{3}{|c|}{ Disagree Agree } & & \\
\hline $\begin{array}{l}\text { 1. Business negotiations with a customer are more } \\
\text { productive in a relaxed atmosphere. }\end{array}$ & 69 & 13 & 49 & 3.72 & 1.15 \\
\hline $\begin{array}{l}\text { 2. The "free lunch" plays an important role in } \\
\text { making sales. }\end{array}$ & 70 & 49 & 20 & 2.39 & 1.33 \\
\hline 3. Trust is easier to establish in a relaxed atmosphere. & 70 & 16 & 51 & 3.64 & 1.20 \\
\hline $\begin{array}{l}\text { 4. A "free lunch" is an expression of gratitude for } \\
\text { doing business. }\end{array}$ & 70 & 26 & 47 & 3.27 & 1.35 \\
\hline $\begin{array}{l}\text { 5. Lunches are considered part of my total } \\
\text { "compensation package." }\end{array}$ & 69 & 66 & 13 & 1.93 & 1.37 \\
\hline $\begin{array}{l}\text { 6. The concept of the "free lunch" is an integral } \\
\text { part of global business practices. }\end{array}$ & 70 & 25 & 40 & 3.29 & 1.26 \\
\hline $\begin{array}{l}\text { 7. The business lunch is an important means } \\
\text { of developing business relationships. }\end{array}$ & 70 & 18 & 58 & 3.73 & 1.24 \\
\hline $\begin{array}{l}\text { 8. A business lunch allows me to gain personal } \\
\text { understanding of those with whom I deal. }\end{array}$ & 70 & 8 & 69 & 4.09 & 1.09 \\
\hline $\begin{array}{l}\text { 9. The "free lunch" is a subtle payoff for } \\
\text { doing business. }\end{array}$ & 70 & 62 & 21 & 2.06 & 1.42 \\
\hline $\begin{array}{l}\text { 10. No professional can be swayed to make a } \\
\text { decision because of a "free lunch." }\end{array}$ & 70 & 29 & 52 & 3.51 & 1.57 \\
\hline
\end{tabular}

data produced few such differences; however, differences in view based on gender did appear with respect to two of the proposed purposes for the business lunch. Female purchasers disagreed with the legitimacy of two purposes for lunch:

1. The business lunch is an important vehicle to use in developing business relationships.
2. A business lunch allows me to gain a deeper personal understanding of those with whom I deal.

Interestingly, the male purchasers agreed with the legitimacy of these two purposes.

The views of NAPM members differed significantly from those of their nonmember purchasing 
TABLE IV

SIGNIFICANT DIFFERENCES BETWEEN THE PURCHASING AND SALES GROUPS: RESULTS FROM MANN-WHITNEY U-WILCOXON RANK SUM W TESTS

\begin{tabular}{|c|c|c|c|c|c|c|}
\hline & \multicolumn{2}{|c|}{ Purchasing } & \multicolumn{2}{|c|}{ Sales } & \multirow[b]{2}{*}{ Z } & \multirow[b]{2}{*}{$p$} \\
\hline & Mean & S.D. & Mean & S.D. & & \\
\hline Circumstances (Scenarios): & & & & & & \\
\hline 6. The contract has already been awarded. & 4.07 & 1.27 & 4.60 & .82 & -2.97 & $<.01$ \\
\hline \multicolumn{7}{|l|}{ Purposes: } \\
\hline $\begin{array}{l}\text { 1. Business negotiations are more } \\
\text { productive in a relaxed atmosphere. }\end{array}$ & 3.09 & 1.26 & 3.72 & 1.14 & -3.11 & $<.01$ \\
\hline $\begin{array}{l}\text { 2. The "free lunch" plays an important } \\
\text { role in making sales. }\end{array}$ & 1.82 & 1.14 & 2.39 & 1.33 & -2.85 & $<.01$ \\
\hline $\begin{array}{l}\text { 3. Trust is easier to establish in a } \\
\text { relaxed atmosphere. }\end{array}$ & 3.09 & 1.26 & 3.64 & 1.20 & -2.76 & $<.01$ \\
\hline $\begin{array}{l}\text { 4. A "free lunch" is an expression of } \\
\text { gratitude for doing business. }\end{array}$ & 2.77 & 1.28 & 3.27 & 1.35 & -2.43 & $<.05$ \\
\hline $\begin{array}{l}\text { 6. The concept of the "free lunch" is an } \\
\text { integral part of global business practice. }\end{array}$ & 2.77 & 1.26 & 3.29 & 1.26 & -2.49 & $<.01$ \\
\hline $\begin{array}{l}\text { 7. The business lunch is an important means } \\
\text { of developing business relationships. }\end{array}$ & 3.12 & 1.21 & 3.73 & 1.24 & -3.22 & $<.01$ \\
\hline $\begin{array}{l}\text { 8. A business lunch allows me to gain } \\
\text { personal understanding of those with } \\
\text { whom I deal. }\end{array}$ & 3.35 & 1.22 & 4.09 & 1.08 & -4.07 & $<.001$ \\
\hline
\end{tabular}

colleagues on one luncheon scenario. NAPM members believe that there is a significantly lower possibility for ethical conflict to develop in situations where the supplier luncheon partner is involved in a long-term or sole source supplier relationship. Consistent with this view is a second difference between members and nonmembers with respect to one of the purposes for the business lunch. NAPM members agree more strongly that a legitimate function of the lunch is to gain a deeper personal understanding of those with whom they deal.

The study found no significant differences in responses to any of the research questions based on age, job responsibility, or the existence of written ethics policies in the organization.

\section{IMPLICATIONS FOR PURCHASERS}

The bottomline of the study clearly is that the busi ness lunch is alive and well as an element in the daily conduct of buyer-supplier activities. Both the purchasing and sales professionals assessed the differing situations associated with the business lunch as representing relatively low possibilities for ethical conflicts. The greatest possibilities for ethical conflict were associated with scenarios in which the product from a number of suppliers was not differentiated on the basis of either quality or price, or when lunch was accepted or rejected based on a personal feeling about the potential luncheon partner.

There was considerably more disagreement between the two groups when the task was to assess the legitimacy of various purposes for the business lunch. Both groups rejected statements implying that legitimate purposes of a free lunch are to serve as a subtle payoff or as compensation, although the sales group expressed less disagreement with these purposes.

An original objective of the study was to determine specifically what purposes the business lunch does in fact serve. Ironically, the study produced more information about what purposes the business lunch does not serve. Both groups agree that the business lunch does not play an important role in making sales-and that professionals' business decisions cannot be swayed because of personal interactions at lunch. For purchasing personnel, most mean scores for all proposed purposes of the business lunch fell close to the neutral response range. These results were surprising and lead the researchers to question just what purposes the business lunch really serves with respect to the bottom line of the purchasing companies involved. This is a particularly relevant question in view of the fact that the NAPM Principles And Standards Of Purchas ing Practice suggests that purchasing professionals should get involved in business meals only for specific business purposes.

It is particularly interesting to note that women in the purchasing profession differ significantly from their male colleagues in their views of the social or personal aspects of the business lunch. The authors hypothesize that the possibilities for the women's rejection of the legitimacy of these purposes may be related to their perceptions of the existence of an "old boy network" in purchasing, or perhaps to concerns about potential sexual harassment. 
The study produced two significant differences related to NAPM membership. Members were less likely to perceive the potential for ethical conflict in situations involving a sole source or long-term supplier relationship. They were also more willing to agree that a fundamental purpose of the business lunch is to develop a better understanding of the person with whom they deal. Although NAPM standards for years have advocated the avoidance of any activity which may appear to diminish the objectivity of the purchasing decision process, members in this study look favorably on the development of cooperative relationships and strategic alliancesand see little potential for the development of ethical conflicts once the relationships are established.

\section{Observations About This and Future Research}

This study was limited by the fact that it used a self-report format, one in which participants may not have been totally candid. However, the fact that the survey was voluntary and anonymous may have ameliorated this problem to some extent. A second potential problem inherent in this study is the relatively low response rate for purchasers, and particularly for sales representatives (21 percent and 15 percent respectively). These response rates leave open the possibility that individuals who did not return the survey may express opinions that differ from those who did respond.

One area stands out as a primary target for further study. Future research should be directed at what apparently is a major policy conflict in many corporations-the situation in which sales professionals are encouraged to use the business lunch as a sales technique, but purchasing professionals in the same organization are discouraged from accepting these perks. Specifically, what message is being sent by management and how is this inconsistency being interpreted and acted upon? A previous study found that purchasing personnel are less likely to adhere to a written policy prohibiting gratuity acceptance if sales personnel in the same organization are allowed to give gratuities. ${ }^{12}$ As firms feel increasing pressure from society to demonstrate good corporate citizenship, this situation represents an unexplainable policy that is bound to tarnish a firm's public image.

Finally, if business lunches are a means of developing business relationships by facilitating the development of a more complete understanding of the individuals with whom one deals, then future research should attempt to make the connection between these purposes and bottomline measures in buyer-supplier relationships.

\section{REFERENCES}

1. G.F. Cummings, "Are Purchasing Ethics Being Put to the Test?," Iron Age, 1979, vol. 222, pp. 21-24; W.F. Dempsey, A. Bushman, and R.E. Plank, "Personal Inducements of
Industrial Buyers," Industrial Marketing Management, 1980, vol. 9, pp. 281-289.

2. L.B. Forker and R.L. Janson, "Ethical Practices in Purchasing," Journal of Purchasing and Materials Management, vol. 26, no. 1 (1990), pp. 19-26; G.B. Turner, G.S. Taylor and M.F. Hartley, "Ethics Policies and Gratuity Acceptance by Purchasers," International Journal of Purchasing and Materials Management, vol. 30, no. 3 (Summer 1994), pp. 43-47.

3. R.L. Janson and K.I. Warner, "We Present Your Own Values and Beliefs on Ethical Purchasing," Midwest Pur chasing Magazine, August, September, October, November, 1977 (four article series).

4. C.W. Hill, (1990) "Cooperation, Opportunism, and the Invisible Hand: Implications for Transaction Cost Theory," Academy of Management Review, vol. 15, pp. 500513.

5. National Association of Purchasing Management, Princi ples and Standards of Purchasing Practice with Accompanying Guidelines, 1992.

6. A.J. Dubinsky and J.M. Gwin, "Business Ethics: Buyers and Sellers," Journal of Purchasing and Materials Manage ment, vol. 17, no. 1 (Winter 1981), pp. 9-16.

7. P. Bradley, "Purchasing Ethics? The Rest of Business Should Be So Strict," Purchasing, May 4, 1989, pp. 24-25.

8. Forker and Janson, op. cit., pp. 19-26.

9. Dubinsky and Gwin, op. cit., pp. 9-16.

10. Turner, Taylor and Hartley, op. cit., pp. 43-47.

11. J.A. Bellizzi and G.W. Murdock, "Industrial Sales Management in the 1980's," Industrial Marketing Management, vol. 10 (1981), pp. 299-304.

12. Turner, Taylor and Hartley, op. cit., pp. 43-47. 